\title{
A Cross-Experimental Analysis of Coat Color Variations and Morphological Characteristics of the Japanese Wild Mouse, Mus musculus
}

\author{
Taichi A. SUZUKI ${ }^{1,2)}$ and Masahiro A. IWASA ${ }^{1)}$ \\ 1) Department of Animal Science and Resources, College of Bioresource Sciences, Nihon University, Fujisawa, \\ Kanagawa 252-8510, Japan \\ 2) Present Address: Department of Ecology and Evolutionary Biology, University of Arizona, Tucson, Arizona 85721, \\ USA
}

\begin{abstract}
There are many coat colors in the laboratory mouse, Mus musculus. On the basis of traditional genetics, there are four loci, A-D, related to coat color expressions. As shown by previous studies, Japanese wild mice have gray backs and white bellies and are assumed to carry the $A^{w}$ allele at the A (agouti) locus, which is dominant over any other alleles. However, we collected Japanese wild mice from central Honshu with black coats. To understand this black coat expression, we performed cross experiments concerning the four loci using wild-caught mice and DBA/2 laboratory mice from the standpoint of traditional genetics. The offspring of the current crosses showed the wild type, the blackish type, and the intermediate type from some combinations of parents. Considering the coat colors of the offspring, we did not obtain any evidence that the Japanese wild mice always carry the $A^{w}$ allele at the A locus. Furthermore, we were not able to explain the current coat color expressions using the traditional logic with regard to the A-D loci and concluded that it is possible for another locus (loci) to be related to the coat color expressions. On the other hand, skull characteristics and external body measurements of the captured wild mice were fundamentally different from those of DBA/2 and offspring from captured wild mice and DBA/2 combinations. Thus, we concluded that the Japanese wild mice had original criteria from a morphological viewpoint.
\end{abstract}

Key words: agouti, coat color, cross experiment, Japanese wild mouse, morphology

\section{Introduction}

Mus musculus is a well-known house mouse worldwide. Laboratory mice are artificially derived from the house mouse and have many coat colors [1]. The variations in coat color are fundamentally determined by arbitrary allele combinations at four loci (A-D) on the basis of traditional genetics [5, 18]. For example, the albino is expressed by recessive homozygosity, $c / c$, at the $\mathrm{C}$ locus irrespective of any gene combinations at the other loci. In addition, recessive homozygosity, $d / d$, at the $\mathrm{D}$ locus leads to the dilution of any coat colors. Moreover, homo- or heterozygosity of the dominant $A$ allele at the A (agouti) locus and the dominant $B$ allele at the B locus leads to light color bands (usually yellowish bands) and black color expression on hair, respectively, and this combination produces an entirely gray coat in the wild type based on the traditional mouse genetical logic [5]. Thus, the mouse coat colors are caused by multiple gene combinations at multiple loci from a genetic standpoint. Such coat colors are observed in laboratory mice, but these colors are rare in wild mice.

(Received 5 July 2012 / Accepted 21 August 2012)

Address corresponding: M. A. Iwasa, Department of Animal Science and Resources, College of Bioresource Sciences, Nihon University, Fujisawa, Kanagawa 252-8510, Japan

(C)2013 Japanese Association for Laboratory Animal Science 
Wild mice occur in natural conditions in Japan, such as in rice fields, on farms, and in grass fields. Japanese wild mice typically show the wild-type coat color with a gray back and white belly $[7,10,15,16]$. The white belly is considered to be specific to the Japanese wild mouse and is expressed by the $A^{w}$ allele at the A locus, which is dominant over the wild type $A$ allele as the standard dominant gene for the wild coat type in the European mouse [5]. For example, the MSM laboratory strain originated in the Japanese wild mouse from Mishima, Shizuoka Prefecture, Honshu, and apparently carries the white belly coat due to $A^{w}$ allele expression [4]. On the other hand, it is well known that the $a$ allele is recessive to the $A$ allele at the A locus and homozygous state of the $a$ allele ( $a / a)$ leads to an entirely mono-color or plain-color coat without the agouti expression, which carries light color bands on hair [5]. Therefore, the agouti locus is strongly related to coat color variations. Previously, the black coat type of a wild mouse was reported by Kuroda [11] from Tokyo Metropolis, but the genetic background of the expression of such a coat color is unknown. However, it is expected that the mice showing such black coat do not carry the $A^{w}$ allele, at least from a genetic standpoint. If so, the $A^{w}$ allele is not always specific to the Japanese wild mice as a genetic variation.

Japanese wild mice and laboratory mice are sometimes ranked as valid species or subspecies: the former are $M$. molossinus or M. musculus molossinus, and the latter are M. domesticus or M. musculus domesticus and M. musculus or M. musculus musculus [3, 4, 12, 13, 19]. Both taxa have been morphologically and genetically differentiated in previous studies [17]. In particular, Japanese wild mice show specific criteria in some cranial characteristics $[12,19]$.

Experimental mice are used worldwide for life science studies. Thus, a few cases in which laboratory mice have accidentally escaped from the laboratory have probably occurred. In such cases, the genetic characteristics of the laboratory mice could be transferred into wild populations and could be considered the source of contamination. Considering such possibilities and problems, to recognize and confirm the validity of Japanese wild mice, morphological and genetic monitoring for validity would be necessary.

In this study, to evaluate the coat color variation of Japanese wild mice, we performed genetic and morphological analyses on Japanese wild mice.

\section{Materials and Methods}

\section{Mouse samples}

We collected wild mice ( $\mathrm{n}=31$, Table 1 ) from five sites in Fujisawa, Kanagawa Pref., which is near Tokyo Metropolis, Japan (Fig. 1), using Sherman traps $(2 \times 2.5 \times$ 6.5 inches, H.B. Sherman Traps, Inc., Tallahassee, FL, USA) and TIN CAT ${ }^{\circledR}$ Mouse Traps $(10.25 \times 6.25 \times 1.75$ inches, Victor ${ }^{\circledR}$, Woodstream Corp., Lititz, PA, USA) during May 2007 to April 2008. All the individuals were examined for overall length, tail length, hind foot length (sine unguis), and body weight; they were then preserved in the author's (Iwasa) laboratory as specimens (flat skins and skulls/mandibles). We classified the mice as adult or young based on their morphology. All the procedures to collect and to make specimens in this study were according to the Special Committee for the Taxonomic Names and Collections in the Mammal Society of Japan.

\section{Quantitative translation of coat colors}

The back and belly skin of all specimens ( $\mathrm{n}=86$, Tables 1 and 2) was scanned using a personal scanner (GT7300U, Epson, Tokyo, Japan). After scanning, we picked up a square of $100 \times 100$ pixels at the median line point of the chest on the back and belly of each mouse individual. A total of 10,000 pixels in the square were translated for relative RGB indices to control the color for the standard red (vivid red V2 of the Practical Color Coordinate System, Nihon Sikiken Co., Ltd., Tokyo, Japan) using Adobe Photoshop CS. In each individual, we calculated the average indices on the back and belly, and for the RGB indices, the relative $\mathrm{R}$ (red) indices $\left(R_{\mathrm{L}}\right)$ were used for the present color comparison. All specimens were divided into three types: wild type (WL), intermediate black type (IB), and complete black type (BK). We confirmed the differences among the three coat types by the $t$-test $(P=0.01)$.

\section{Cross experiments}

Regarding the wild-caught mice, we performed cross experiments for five combinations, Crosses I-V (Table $3)$, among them $(\mathrm{n}=7)$ and the laboratory mouse $(\mathrm{n}=3)$, DBA/2 (Japan SLC, Inc., Hamamatsu, Japan), which is considered to be the M. musculus musculus type [4], to confirm the coat colors of the offspring obtained from pairings. DBA/2 was the tester mouse for coat color expression because it carries the genetic constitutions of $a / a, b / b, C / C$, and $d / d$ at the standard coat color loci [5]. 
Table 1. Wild-caught and laboratory mice examined in this study

\begin{tabular}{|c|c|c|c|c|c|c|}
\hline \multirow{2}{*}{ Collection locality in Fujisawa } & \multirow{2}{*}{ Specimen No. } & \multirow{2}{*}{ Sex } & \multirow{2}{*}{ Coat type ${ }^{\text {b) }}$} & \multicolumn{2}{|c|}{$R_{\mathrm{L}}$ indices } & \multirow{2}{*}{$\begin{array}{l}\text { Zyg. } \\
\text { plate }\end{array}$} \\
\hline & & & & Back & Belly & \\
\hline \multirow{8}{*}{$\begin{array}{l}\text { 1. Warehouse of Nihon Univ. } \\
\left(35^{\circ} 22^{\prime} 42^{\prime \prime} \mathrm{N}, 139^{\circ} 28^{\prime} 07^{\prime \prime} \mathrm{E}\right)\end{array}$} & NUWL-M153 & $\mathrm{f}$ & WL & 0.204 & 0.822 & $\mathrm{C}$ \\
\hline & NUWL-M154 & $\mathrm{f}$ & WL & 0.252 & 0.821 & $\mathrm{C}$ \\
\hline & NUWL-M156 & $\mathrm{f}$ & WL & 0.254 & 0.876 & $\mathrm{C}$ \\
\hline & NUWL-M164 & $\mathrm{f}$ & WL & 0.194 & 0.891 & $\mathrm{C}$ \\
\hline & NUWL-M172a) & $\mathrm{m}$ & WL & 0.205 & 0.905 & $\mathrm{C}$ \\
\hline & NUWL-M173 & $\mathrm{f}$ & WL & 0.168 & 0.915 & $\mathrm{C}$ \\
\hline & NUWL-M174 & $\mathrm{m}$ & WL & 0.175 & 0.900 & $\mathrm{C}$ \\
\hline & NUWL-M175 & $\mathrm{f}$ & WL & 0.139 & 0.761 & $\mathrm{C}$ \\
\hline \multirow{10}{*}{$\begin{array}{l}\text { 2. Farm of Nihon Univ. } \\
\left(35^{\circ} 22^{\prime} 35^{\prime} \mathrm{N}, 139^{\circ} 27^{\prime} 49^{\prime \prime} \mathrm{E}\right)\end{array}$} & NUWL-M77 & $\mathrm{f}$ & WL & 0.074 & 0.836 & $\mathrm{C}$ \\
\hline & NUWL-M94 & $\mathrm{m}$ & WL & 0.119 & 0.846 & $\mathrm{C}$ \\
\hline & NUWL-M95 & $\mathrm{m}$ & WL & 0.115 & 0.815 & $\mathrm{C}$ \\
\hline & NUWL-M97 & $\mathrm{f}$ & WL & 0.095 & 0.725 & $\mathrm{C}$ \\
\hline & NUWL-M113a) & $\mathrm{m}$ & WL & 0.139 & 0.930 & $\mathrm{C}$ \\
\hline & NUWL-M116 & $\mathrm{f}$ & WL & 0.130 & 0.985 & $\mathrm{C}$ \\
\hline & NUWL-M115 & $\mathrm{m}$ & WL & 0.099 & 0.706 & $\mathrm{C}$ \\
\hline & NUWL-M147ª) & $\mathrm{f}$ & IB & 0.074 & 0.634 & $\mathrm{C}$ \\
\hline & NUWL-M155a) & $\mathrm{f}$ & BK & 0.064 & 0.284 & $\mathrm{C}$ \\
\hline & NUWL-M171 a) & $\mathrm{f}$ & IB & 0.078 & 0.453 & $\mathrm{C}$ \\
\hline \multirow{12}{*}{$\begin{array}{l}\text { 3. Grass fields and farms at Ohba area } \\
\left(35^{\circ} 21^{\prime} 24^{\prime} \mathrm{N}, 139^{\circ} 27^{\prime} 14^{\prime \prime} \mathrm{E}\right)\end{array}$} & NUWL-M98'a) & $\mathrm{m}$ & WL & 0.154 & 0.926 & $\mathrm{C}$ \\
\hline & NUWL-M99 & $\mathrm{f}$ & WL & 0.100 & 0.767 & $\mathrm{C}$ \\
\hline & NUWL-M106 & $\mathrm{m}$ & WL & 0.108 & 0.854 & $\mathrm{C}$ \\
\hline & NUWL-M107 & $\mathrm{f}$ & WL & 0.149 & 0.698 & $\mathrm{C}$ \\
\hline & NUWL-M109 & $\mathrm{m}$ & WL & 0.080 & 0.806 & $\mathrm{C}$ \\
\hline & NUWL-M110 & $\mathrm{f}$ & WL & 0.119 & 0.861 & $\mathrm{C}$ \\
\hline & NUWL-M112 & $\mathrm{m}$ & WL & 0.119 & 0.797 & $\mathrm{C}$ \\
\hline & NUWL-M128 & $\mathrm{m}$ & IB & 0.074 & 0.607 & $\mathrm{C}$ \\
\hline & NUWL-M157 & $\mathrm{f}$ & WL & 0.179 & 0.920 & $\mathrm{C}$ \\
\hline & NUWL-M163 & $\mathrm{f}$ & WL & 0.074 & 0.697 & $\mathrm{C}$ \\
\hline & NUWL-M166 & $\mathrm{m}$ & WL & 0.194 & 0.756 & $\mathrm{C}$ \\
\hline & NUWL-M167 & $\mathrm{f}$ & IB & 0.079 & 0.458 & $\mathrm{C}$ \\
\hline \multirow{2}{*}{$\begin{array}{l}\text { 4. Riverside of Hikiji Riv. } \\
\left(35^{\circ} 22^{\prime} 03^{\prime \prime} \mathrm{N}, 139^{\circ} 27^{\prime} 24^{\prime \prime} \mathrm{E}\right)\end{array}$} & NUWL-M108 & $\mathrm{m}$ & WL & 0.140 & 0.776 & $\mathrm{C}$ \\
\hline & NUWL-M120 & $\mathrm{m}$ & WL & 0.120 & 0.845 & $\mathrm{C}$ \\
\hline \multirow[t]{4}{*}{147 's offspring } & NUWL-M96 & $\mathrm{m}$ & IB & 0.089 & 0.562 & $\mathrm{C}$ \\
\hline & NUWL-M117 & $\mathrm{f}$ & IB & 0.069 & 0.517 & $\mathrm{C}$ \\
\hline & NUWL-M118 & $\mathrm{m}$ & IB & 0.074 & 0.587 & $\mathrm{C}$ \\
\hline & NUWL-M168 & $\mathrm{f}$ & BK & 0.094 & 0.264 & $\mathrm{C}$ \\
\hline \multirow[t]{5}{*}{163 's offspring } & NUWL-M144 & $\mathrm{m}$ & WL & 0.165 & 1.125 & $\mathrm{C}$ \\
\hline & NUWL-M145 & $\mathrm{m}$ & WL & 0.120 & 0.890 & $\mathrm{C}$ \\
\hline & NUWL-M146 & $\mathrm{m}$ & WL & 0.104 & 0.847 & $\mathrm{C}$ \\
\hline & NUWL-M165 & $\mathrm{f}$ & WL & 0.100 & 0.730 & $\mathrm{C}$ \\
\hline & NUWL-M170 & $\mathrm{f}$ & WL & 0.205 & 0.965 & $\mathrm{C}$ \\
\hline
\end{tabular}

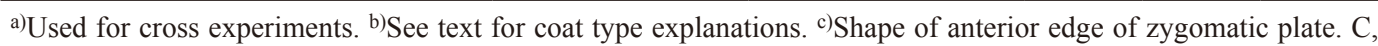
strongly convex; S, straight.

Regarding the five cross combination pairs, mating was performed twice with pairs for Crosses I, II, and V (Table 3). To determine the adult coat color, we made skin specimens of the offspring 90 days after birth. All experimental procedures were conducted in accordance with the guidelines for animal experiments, College of Bioresource Sciences, Nihon University.

\section{Morphological analysis}

All the individuals ( $\mathrm{n}=87-89$ including three individuals of DBA/2, Tables 1, 3, and 4) were measured for total length (TL), tail length (T), hind foot length sine unguis (HFsu), body weight (BW), and condylobasal length of the skull (CBL). We recognized wild-caught mice with a CBL of over $17.0 \mathrm{~mm}$ as being in the adult stage. 


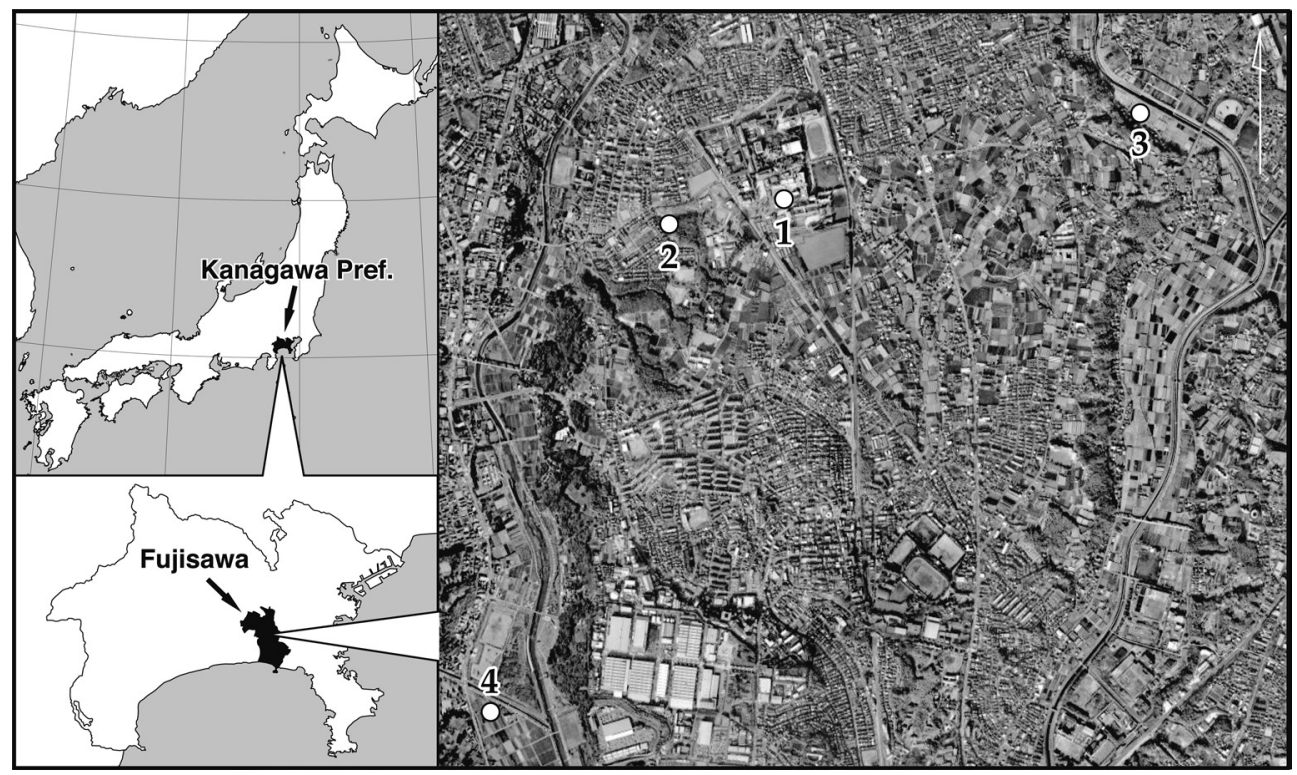

Fig. 1. Collection localities of wild-caught mice examined in this study. Numbers are identical to those of Table 1. This Landsat photo is from Google Earth 4.0.2.

Table 2. $\mathrm{R}_{\mathrm{L}}$ indices (mean $\pm \mathrm{SD}$ ) of the three coat types for the back and belly of all the mice examined in this study

\begin{tabular}{|c|c|c|}
\hline & Back & Belly \\
\hline \multicolumn{3}{|c|}{ Wild-caught mice $\left.{ }^{a}\right)$} \\
\hline WL $(n=32)$ & $0.1435 \pm 0.0483$ & $0.8436 \pm 0.0935$ \\
\hline IB $(n=7)$ & $0.0748 \pm 0.0064$ & $0.5600 \pm 0.0664$ \\
\hline $\mathrm{BK}(\mathrm{n}=2)$ & $0.0640 \pm 0.0000$ & $0.2740 \pm 0.0141$ \\
\hline \multicolumn{3}{|c|}{ Offspring by cross experiments } \\
\hline WL (n=34) & $0.1351 \pm 0.0324$ & $0.8436 \pm 0.1322$ \\
\hline IB $(n=3)$ & $0.0657 \pm 0.0058$ & $0.5900 \pm 0.0597$ \\
\hline $\mathrm{BK}(\mathrm{n}=9)$ & $0.0723 \pm 0.0079$ & $0.2169 \pm 0.0170$ \\
\hline
\end{tabular}

a)Including offspring of NUWL-M147 and 163.

To evaluate the validity of Japanese wild mice, we compared the external morphological dimensions and observed the anterior edge of the zygomatic plate on the lateral view in all the skull specimens. In the anterior edge shape, there was a clear difference between the Japanese wild mouse (the molossinus type) and the laboratory mouse (the domesticus/musculus types), including the DBA strains $[3,12,19]$.

\section{Results}

\section{Coat color variations}

We were able to collect 41 individuals from the four sites (Table 1 and Fig. 1). Of them, 32, 7, and 2 indi- viduals were classified as WL, IB, and BK, respectively, on the basis of the $R_{\mathrm{L}}$ indices on the belly (Table 1, and Fig. 2). The $R_{\mathrm{L}}$ indices of all individuals are shown in Tables 1 and 2. Among the three coat types, there were significant differences for the $R_{\mathrm{L}}$ indices among all the pairwise comparisons on the back and belly by the student's $t$-test $(P<0.01)$.

\section{Cross experiments}

We performed cross experiments as shown in Table 3. To confirm the coat color expressions related to the A locus, some wild-caught mice were crossed with wildcaught mice and DBA/2 mice. Regarding the first mating of the two pairs of wild-caught mice, all the offspring of NUWL-M116 (WL)/113 (WL) had WL coats and white bellies, and regarding the offspring of NUWL-M 147 (IB)/98 (WL), one had an IB coat and three had WL coats (Table 3 and Fig. 3). In addition, the pair of NUWL-M172 (WL)/200 (DBA/2) produced all WL coat offspring, and the pair of NUWL-M155 (BK)/114 (DBA/2) produced all BK coat offspring (Table 3 and Fig. 3). However, the pair of NUWL-M171 (IB)/202 (DBA/2) showed both IB and BK coats in its offspring (Table 3 and Fig. 3).

\section{Morphological characteristics}

The five morphological measurements were compared among four categories, the wild-caught mice, DBA/2 
Table 3. Results of cross experiments in this study

\begin{tabular}{|c|c|c|c|c|c|c|c|}
\hline & & Sor & Cont tume & & & Snocimon No & Zyg.b) \\
\hline & & & & Back & Belly & & plate \\
\hline Cross I & $\mathrm{P}$ & $\mathrm{f}$ & WL & 0.130 & 0.985 & NUWL-M116 & $\mathrm{C}$ \\
\hline & $\mathrm{P}$ & $\mathrm{m}$ & WL & 0.139 & 0.930 & NUWL-M113 & $\mathrm{C}$ \\
\hline & $\mathrm{F}_{1}(1)^{\mathrm{a})}$ & $\mathrm{f}$ & WL & 0.158 & 0.970 & NUWL-M122 & $\mathrm{C}$ \\
\hline & & $\mathrm{f}$ & WL & 0.158 & 0.995 & NUWL-M123 & $\mathrm{C}$ \\
\hline & & $\mathrm{f}$ & WL & 0.149 & 1.005 & NUWL-M124 & $\mathrm{C}$ \\
\hline & & $\mathrm{f}$ & WL & 0.154 & 0.990 & NUWL-M125 & $\mathrm{C}$ \\
\hline & & $\mathrm{m}$ & WL & 0.159 & 1.050 & NUWL-M126 & $\mathrm{C}$ \\
\hline & & $\mathrm{m}$ & WL & 0.179 & 1.020 & NUWL-M127 & $\mathrm{C}$ \\
\hline & $\mathrm{F}_{1}(2)^{\mathrm{a})}$ & $\mathrm{m}$ & WL & 0.179 & 1.025 & NUWL-M134 & $\mathrm{C}$ \\
\hline & & $\mathrm{m}$ & WL & 0.184 & 1.050 & NUWL-M135 & $\mathrm{C}$ \\
\hline & & $\mathrm{f}$ & WL & 0.159 & 0.990 & NUWL-M136 & $\mathrm{C}$ \\
\hline & & $\mathrm{f}$ & WL & 0.149 & 0.890 & NUWL-M137 & $\mathrm{C}$ \\
\hline & & $\mathrm{m}$ & WL & 0.169 & 1.020 & NUWL-M138 & $\mathrm{C}$ \\
\hline Cross II & $\mathrm{P}$ & $\mathrm{f}$ & IB & 0.074 & 0.634 & NUWL-M147 & $\mathrm{C}$ \\
\hline & $\mathrm{P}$ & $\mathrm{m}$ & WL & 0.154 & 0.926 & NUWL-M98 & $\mathrm{C}$ \\
\hline & $\mathrm{F}_{1}(1)^{\mathrm{a})}$ & $\mathrm{f}$ & IB & 0.059 & 0.614 & NUWL-M140 & $\mathrm{C}$ \\
\hline & & $\mathrm{m}$ & WL & 0.079 & 0.731 & NUWL-M141 & $\mathrm{C}$ \\
\hline & & $\mathrm{f}$ & WL & 0.163 & 1.025 & NUWL-M142 & $\mathrm{C}$ \\
\hline & & $\mathrm{f}$ & WL & 0.080 & 0.762 & NUWL-M143 & $\mathrm{C}$ \\
\hline & $\mathrm{F}_{1}(2)^{\mathrm{a})}$ & $\mathrm{f}$ & WL & 0.069 & 0.752 & NUWL-M158 & $\mathrm{C}$ \\
\hline & & f & IB & 0.069 & 0.634 & NUWL-M160 & $\mathrm{C}$ \\
\hline & & $\mathrm{m}$ & WL & 0.183 & 1.010 & NUWL-M161 & $\mathrm{C}$ \\
\hline & & $\mathrm{m}$ & WL & 0.129 & 0.856 & NUWL-M162 & $\mathrm{C}$ \\
\hline Cross III & $\mathrm{P}$ & $\mathrm{f}$ & $\mathrm{BK}$ & 0.064 & 0.284 & NUWL-M155 & $\mathrm{C}$ \\
\hline & $\mathrm{P}$ & $\mathrm{m}$ & $\mathrm{DBA} / 2$ & 0.383 & 0.597 & NUWL-M114 & $\mathrm{S}$ \\
\hline & $\mathrm{F}_{1}$ & $\mathrm{~m}$ & BK & 0.069 & 0.198 & NUWL-M148 & $\mathrm{S}$ \\
\hline & & $\mathrm{m}$ & $\mathrm{BK}$ & 0.074 & 0.227 & NUWL-M149 & $\mathrm{S}$ \\
\hline & & $\mathrm{m}$ & $\mathrm{BK}$ & 0.079 & 0.199 & NUWL-M150 & $\mathrm{S}$ \\
\hline & & $\mathrm{m}$ & $\mathrm{BK}$ & 0.079 & 0.208 & NUWL-M151 & $\mathrm{S}$ \\
\hline & & $\mathrm{f}$ & $\mathrm{BK}$ & 0.074 & 0.209 & NUWL-M152 & $\mathrm{S}$ \\
\hline Cross IV & $\mathrm{P}$ & $\mathrm{f}$ & IB & 0.078 & 0.453 & NUWL-M171 & $\mathrm{C}$ \\
\hline & $\mathrm{P}$ & $\mathrm{m}$ & $\mathrm{DBA} / 2$ & 0.363 & 0.551 & NUWL-M202 & $\mathrm{S}$ \\
\hline & $\mathrm{F}_{1}$ & $\mathrm{f}$ & BK & 0.054 & 0.249 & NUWL-M184 & $\mathrm{S}$ \\
\hline & & $\mathrm{f}$ & IB & 0.069 & 0.522 & NUWL-M185 & $\mathrm{S}$ \\
\hline & & $\mathrm{f}$ & $\mathrm{BK}$ & 0.074 & 0.209 & NUWL-M186 & $\mathrm{S}$ \\
\hline & & $\mathrm{m}$ & $\mathrm{BK}$ & 0.069 & 0.234 & NUWL-M187 & $\mathrm{S}$ \\
\hline & & $\mathrm{f}$ & $\mathrm{BK}$ & 0.079 & 0.219 & NUWL-M188 & $\mathrm{S}$ \\
\hline Cross V & $\mathrm{P}$ & $\mathrm{f}$ & $\mathrm{DBA} / 2$ & 0.307 & 0.518 & NUWL-M200 & $\mathrm{S}$ \\
\hline & $\mathrm{P}$ & $\mathrm{m}$ & WL & 0.205 & 0.905 & NUWL-M172 & $\mathrm{C}$ \\
\hline & $\mathrm{F}_{1}(1)^{\mathrm{a})}$ & $\mathrm{f}$ & WL & 0.095 & 0.756 & NUWL-M176 & $\mathrm{S}$ \\
\hline & & $\mathrm{f}$ & WL & 0.105 & 0.733 & NUWL-M177 & $\mathrm{S}$ \\
\hline & & $\mathrm{f}$ & WL & 0.114 & 0.755 & NUWL-M178 & $\mathrm{S}$ \\
\hline & & $\mathrm{m}$ & WL & 0.090 & 0.741 & NUWL-M179 & $\mathrm{S}$ \\
\hline & & $\mathrm{m}$ & WL & 0.100 & 0.760 & NUWL-M180 & $\mathrm{S}$ \\
\hline & & $\mathrm{m}$ & WL & 0.126 & 0.775 & NUWL-M181 & $\mathrm{S}$ \\
\hline & & $\mathrm{m}$ & WL & 0.130 & 0.740 & NUWL-M182 & $\mathrm{S}$ \\
\hline & & $\mathrm{m}$ & WL & 0.125 & 0.759 & NUWL-M183 & $\mathrm{S}$ \\
\hline & $\mathrm{F}_{1}(2)^{\mathrm{a})}$ & $\mathrm{f}$ & WL & 0.110 & 0.755 & NUWL-M189 & $\mathrm{S}$ \\
\hline & & $\mathrm{f}$ & WL & 0.136 & 0.740 & NUWL-M190 & $\mathrm{S}$ \\
\hline & & $\mathrm{f}$ & WL & 0.124 & 0.730 & NUWL-M191 & $\mathrm{S}$ \\
\hline & & $\mathrm{m}$ & WL & 0.175 & 0.710 & NUWL-M192 & $\mathrm{S}$ \\
\hline & & $\mathrm{m}$ & WL & 0.135 & 0.697 & NUWL-M193 & $\mathrm{S}$ \\
\hline & & $\mathrm{m}$ & WL & 0.105 & 0.745 & NUWL-M194 & $\mathrm{S}$ \\
\hline & & $\mathrm{m}$ & WL & 0.145 & 0.701 & NUWL-M195 & $\mathrm{S}$ \\
\hline & & $\mathrm{m}$ & WL & 0.159 & 0.740 & NUWL-M196 & $\mathrm{S}$ \\
\hline & & $\mathrm{m}$ & WL & 0.119 & 0.705 & NUWL-M197 & $\mathrm{S}$ \\
\hline
\end{tabular}

a)(1), first mating; (2), second mating by the same pair as first mating. ${ }^{\text {b) Shape of anterior edge of }}$ zygomatic plate. $\mathrm{C}$, strongly convex; $\mathrm{S}$, straight. 


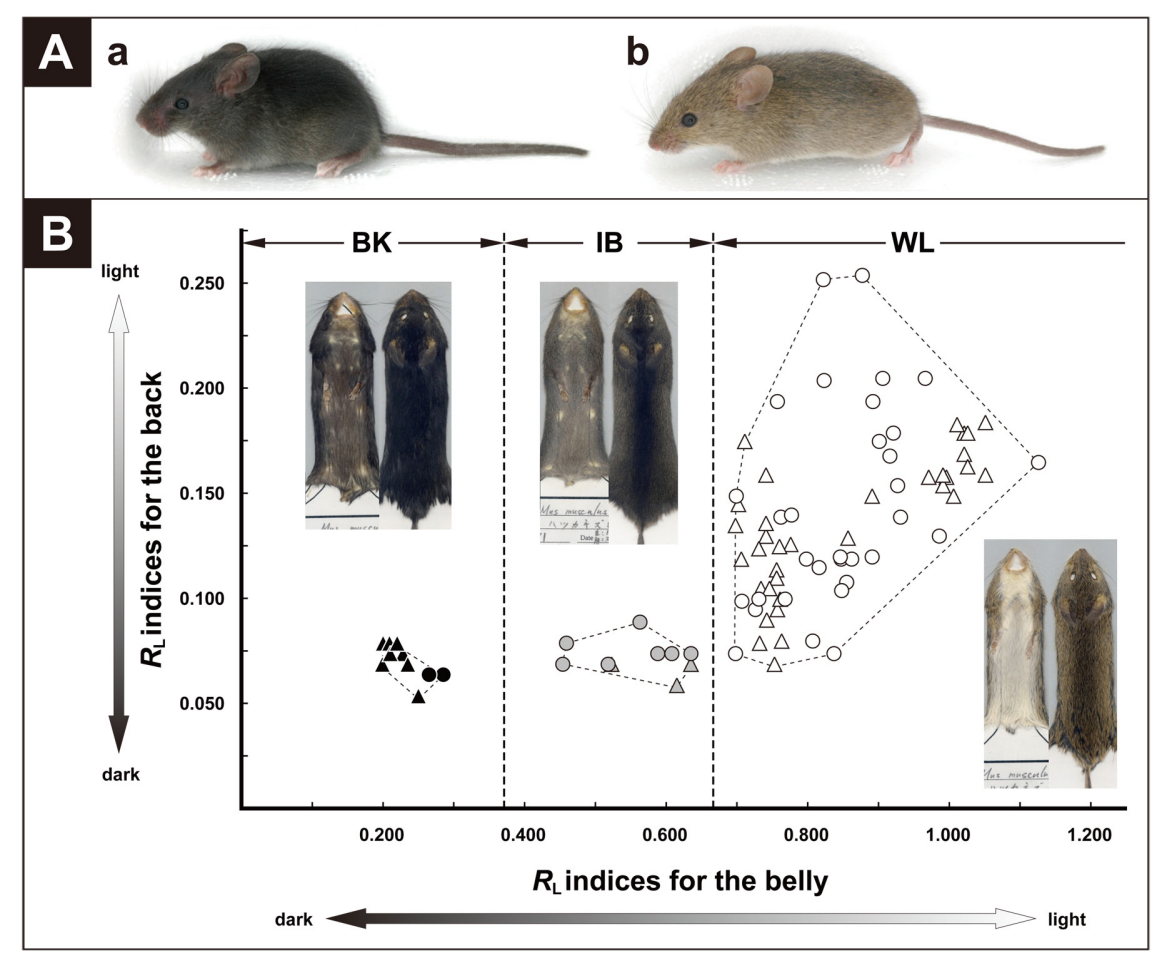

Fig. 2. Typical appearances (A) of the IB type coat (a) and WL coat (b). Scatter plots (B) between the $R_{\mathrm{L}}$ indices for the back and belly. We defined WL (white symbols), IB (gray symbols) and BK (black symbols) types as shown. Circles and triangles indicate wildcaught mice and offspring from cross experiments, respectively. Photos of the belly (left) and back (right) are typical examples of three types.

mice, the offspring of crosses between the wild-caught and DBA/2 mice, and the offspring of the wild-caught mice, considering the WL and blackish (IB-BK) coat color types (Table 4 and Fig. 4). Interestingly, most characteristics of the offspring of the wild-caught and DBA/2 mice (including both coat types) were similar to those of DBA/2 mice. In addition, most measurements of the wild-caught mice were significantly different from those of DBA/2 mice and the offspring of the wild-caught and DBA/2 mice, irrespective of the coat color types (Table 4 and Fig. 4). According to the present statistical analysis of five morphological characteristics, at least, there are fundamentally no differences in the morphological dimensions between the WL and IB-BK coat types in each category.

All the wild-caught mice showed a strongly convex type (the molossinus type) for the anterior edge of the zygomatic plate (Table 1). On the other hand, all the offspring of all the cross experiments using DBA/2 showed the straight type (Table 3 ). The $\mathrm{F}_{1}$ animals of all the experiments with DBA/2 were morphologically clas- sified into the laboratory mouse type (the domesticus/ musculus type).

\section{Discussion}

\section{Origin of the BK coat}

The present BK mice were obtained near the campus of Nihon University, which keeps many laboratory mice. Thus, there was the possibility that they were derived from laboratory mice. However, the present data from the morphological analysis revealed that the current mouse samples were different from those of laboratory mice, such as DBA/2, which is derived from $M$. musculus musculus [4] (Table 4 and Fig. 4). Accordingly, we conclude that the present wild-caught mice are typically Japanese wild mice.

Irrespective of the coat color types, the offspring of wild-caught mice and DBA/2 interestingly showed intermediate types from a morphological standpoint. Some of the morphological dimensions were similar to those of the wild-caught mice, and others were similar to those 


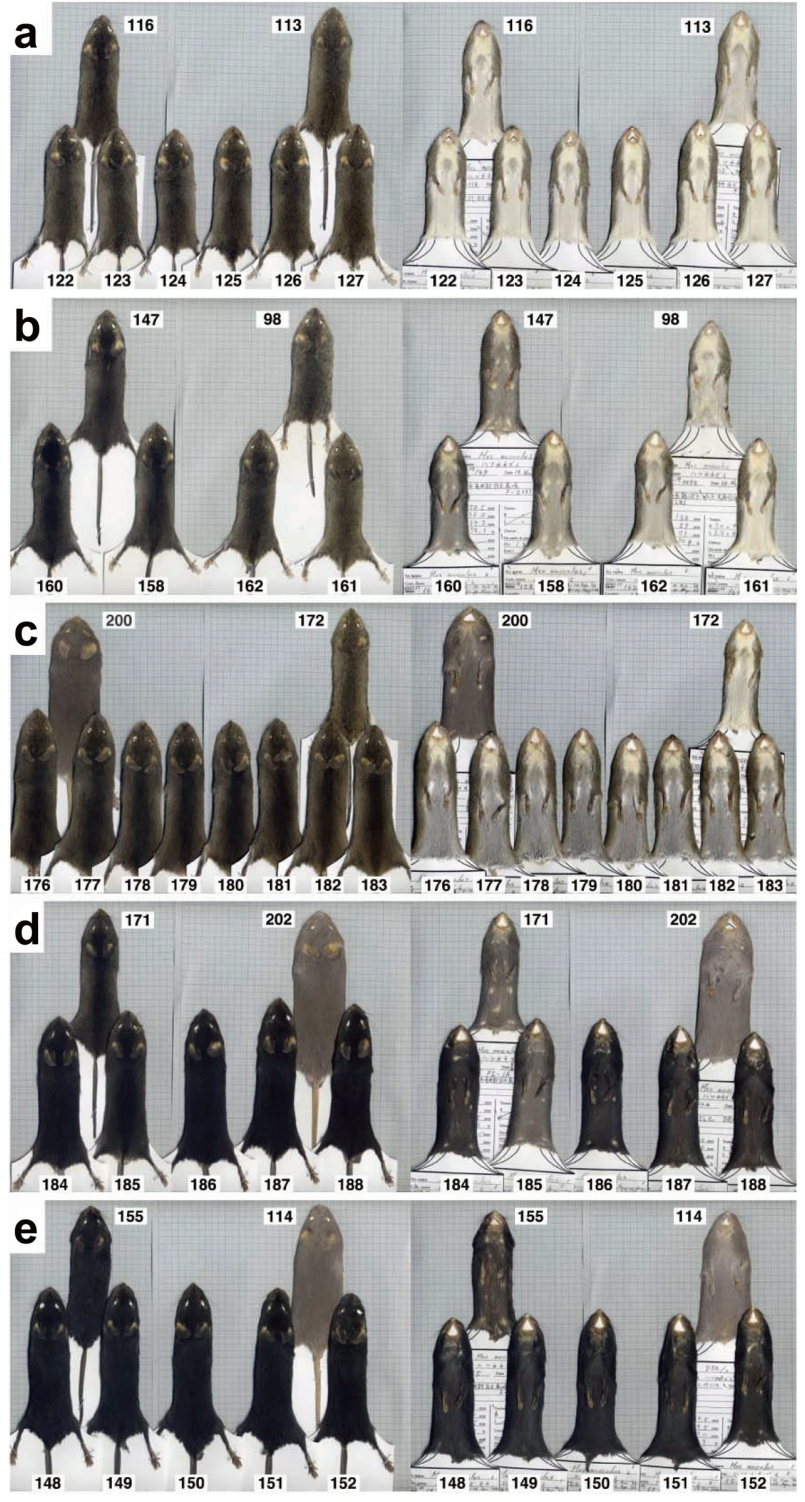

Fig. 3. Coat colors of offspring from cross experiments for the WL type $\times$ WL type (a), IB type $\times$ WL type $(b)$, DBA $/ 2 \times$ WL type (c), IB type $\times$ DBA $/ 2(d)$, and BK type $\times$ WL type (e). All the specimens are represented as back at left and belly at right. Upper left and right animals are the female and male parents, respectively, and the lower animals are offspring. All the numbers represent NUWL-M series specimen Nos.

of DBA/2 (Table 4 and Fig. 4). This fact is evidence that the wild-caught mice are not laboratory mice or descendants of laboratory mice. In the present analysis, the measurements in HFsu of the offspring of the wildcaught and DBA/2 mice showing the IB-BK coat type were divided into lower and higher sizes (Fig. 4). We cannot suggest critical mechanisms leading to these two size groups at present, but the hind foot size may be a neutral character in their viability under natural conditions.

\section{Expression of the BK coat}

Using laboratory mice, it has been shown that the expression of the back color is regulated by the A locus and the melanocortin 1 receptor gene $(M c 1 r)[14,20]$. In addition, hairs of the current BK coat appeared to be non-banded hairs (the so-called non-agouti type), contrary to the agouti-type hairs carrying light color bands, and such non-banded hairs are derived from $a / a$ expression at the A locus [18]. On the basis of the theoretical background of the A locus expression, we performed cross experiments between $\mathrm{BK}$ and $\mathrm{DBA} / 2$ mice. We anticipated that the BK mice would be non-agouti with $a / a$ and that their offspring would be shown to be BK mice carrying $a / a$. The results of the cross experiments showed that all offspring were BK mice carrying $a / a$ (Table 3). Therefore, our assumptions appear to be reasonable at present. On the other hand, we performed a cross between the IB and DBA/2 mice, and the IB and BK offspring were obtained (Table 3 ). Furthermore, both IB and BK offspring were obtained from a captured wild pregnant mouse showing an IB coat color type (Table 3). Considering these facts, the IB mouse most likely carries the $a$ allele at least. According to the above findings from the cross experiments, it is possible that our results regarding the coat color are not only explained by the A locus but also by the variants of $M c 1 r$, which are related to melanin expression $[8,9,14]$. Therefore, more analysis about both loci is necessary to evaluate the IB and BK expressions in Japanese wild mice.

\section{High frequency of black coat mice under natural conditions}

Hamajima [6] reported that there was a lower frequency (7-8\%) of collection of black coat mice under natural conditions. However, the current frequency of collection of IB and BK coat mice was 16.1\% (5/31), relatively higher than the results of Hamajima [6] (Table 1). Furthermore, the IB and BK mice were obtained from only localities 2 and 3 (Table 1 and Fig. 1).

Our collection localities were separated from each other by houses, roads, and some artificial constructions. Therefore, it is expected that each population may be limited to some degree from genetic exchanges with other populations. Such isolation has a bottleneck effect 
Table 4. Summarized morphological differences among seven mouse types, DBA/2 (DBA) mice, $\mathrm{F}_{1}$ mice derived from a wild-caught mouse and DBA/2 (Wild $\times$ DBA) with WL and IB-BK types, wild-caught mice (Wild) with WL and IB-BK types, $\mathrm{F}_{1}$ mice derived from wild-caught mice (Wild $\times$ Wild) with WL and IB-BK types for the five measurements by $t$-test

\begin{tabular}{|c|c|c|c|c|c|c|c|}
\hline & & $\begin{array}{l}\text { DBA } \\
(n=3)\end{array}$ & $\begin{array}{c}\text { Wild } \times \text { DBA } \\
(\text { WL })\end{array}$ & $\begin{array}{c}\text { Wild } \times \text { DBA } \\
(\text { IB \& BK) }\end{array}$ & $\begin{array}{l}\text { Wild } \\
\text { (WL) }\end{array}$ & $\begin{array}{c}\text { Wild } \\
\text { (IB \& BK) }\end{array}$ & $\begin{array}{l}\text { Wild } \times \text { Wild } \\
\quad(\text { WL })\end{array}$ \\
\hline \multirow[t]{6}{*}{$\mathrm{BW}^{\mathrm{a})}$} & Wild $\times$ DBA $(W L, n=17)$ & ++ & - & & & & \\
\hline & Wild $\times$ DBA $($ IB-BK, $n=10)$ & ++ & ns & - & & & \\
\hline & Wild (WL, n=31) & ++ & ++ & ++ & - & & \\
\hline & Wild (IB-BK, n=9) & ++ & ++ & ++ & ns & - & \\
\hline & Wild $\times$ Wild $(W L, n=17)$ & ++ & ++ & ++ & ns & ns & - \\
\hline & Wild $\times$ Wild $($ IB-BK, $n=2)$ & ++ & ++ & ++ & ns & ns & ns \\
\hline \multirow[t]{6}{*}{$\mathrm{HB}^{\mathrm{a})}$} & Wild $\times$ DBA $($ WL,$n=17)$ & ++ & - & & & & \\
\hline & Wild $\times$ DBA $($ IB-BK, $n=10)$ & ++ & ++ & - & & & \\
\hline & Wild (WL, n=31) & ++ & ++ & ++ & - & & \\
\hline & Wild (IB-BK, n=9) & ++ & ++ & ++ & ns & - & \\
\hline & Wild $\times$ Wild $(W L, n=17)$ & ++ & ++ & ++ & ns & ns & - \\
\hline & Wild $\times$ Wild (IB-BK, $n=2)$ & ++ & ns & ns & ns & ns & ns \\
\hline \multirow[t]{6}{*}{$\mathrm{T}^{\mathrm{a})}$} & Wild $\times$ DBA $($ WL,$n=17)$ & + & - & & & & \\
\hline & Wild $\times$ DBA $($ IB-BK, $n=10)$ & ++ & ++ & - & & & \\
\hline & Wild (WL, n=31) & ++ & ++ & ++ & - & & \\
\hline & Wild (IB-BK, n=9) & ++ & ++ & ++ & ++ & - & \\
\hline & Wild $\times$ Wild $(W L, n=17)$ & ++ & ++ & ++ & + & ns & - \\
\hline & Wild $\times$ Wild $($ IB-BK, $n=2)$ & ++ & ++ & ++ & ++ & + & ns \\
\hline \multirow[t]{6}{*}{$\mathrm{HFsu}^{\text {a) }}$} & Wild $\times$ DBA $($ WL,$n=17)$ & ns & - & & & & \\
\hline & Wild $\times$ DBA $($ IB-BK, $n=10)$ & ++ & ++ & - & & & \\
\hline & Wild (WL, $\mathrm{n}=31$ ) & ++ & ++ & ns & - & & \\
\hline & Wild (IB-BK, $n=9$ ) & ++ & ++ & ns & ns & - & \\
\hline & Wild $\times$ Wild $(W L, n=17)$ & ++ & ++ & ns & ++ & ns & - \\
\hline & Wild $\times$ Wild $($ IB-BK, $n=2)$ & ns & ns & ns & ns & ns & ns \\
\hline \multirow[t]{6}{*}{$\mathrm{CBL}^{\mathrm{a})}$} & Wild $\times$ DBA $($ WL,$n=15)$ & ns & - & & & & \\
\hline & Wild $\times$ DBA $($ IB-BK, $n=10)$ & ns & + & - & & & \\
\hline & Wild (WL, n=31) & ++ & ++ & ++ & - & & \\
\hline & Wild (IB-BK, n=9) & ++ & ++ & ++ & ++ & - & \\
\hline & Wild $\times$ Wild $(W L, n=17)$ & ++ & ++ & ++ & + & ++ & - \\
\hline & Wild $\times$ Wild $($ IB-BK, $n=2)$ & + & ++ & ++ & ++ & ns & ++ \\
\hline
\end{tabular}

++ , significant at $P=0.01 ;+$, significant at $P=0.05$; ns, not significant. ${ }^{\text {a) }}$ See text for abbreviations.

on the populations, resulting in higher homozygous states of recessive genes. For example, at the A locus, the frequency of the $a / a$ would be increased by the bottleneck, and the frequency of the non-agouti black color would also be increased. As well as the $a / a$ frequency, the $c / c$ showing albino characteristics at the $\mathrm{C}$ locus would also be expected to increase. However, predators more easily detect albino mice than black ones, and the viability of the black mice is thus superior to that of albino mice under natural conditions. In conclusion, black mice have superior viability, as do WL mice.

\section{Reevaluation of the agouti genes in Japanese wild mice}

Usually, it is considered that the $A$ and $A^{w}$ alleles at the A locus are dominant and that Japanese wild mice carry the $A^{w}$ allele and have white bellies [2]. The MSM mouse strain originated from Japanese wild mice and is characterized by its white belly. In addition, the $A^{w}$ allele is dominant over all alleles described by lowercase symbols at the A locus [5]. Considering these findings, any offspring of a mouse carrying the $A^{w}$ allele would be expected to have a white belly. However, our cross experiment results showed unexpected expressions with regard to coat colors (Table 3 and Fig. 3). Thus, we suggest that the property of both $A^{w}$ allele and white belly is not always recognized in Japanese wild mice and that other loci may be related to the coat color phenotype.

\section{Acknowledgments}

We are grateful to Dr. Hitoshi Suzuki (Hokkaido Univ.) for his invaluable comments regarding an early draft the manuscript. Special thanks are also due to Drs. Yutaka Yamamuro (Nihon Univ.), Kimiyuki Tsuchiya 


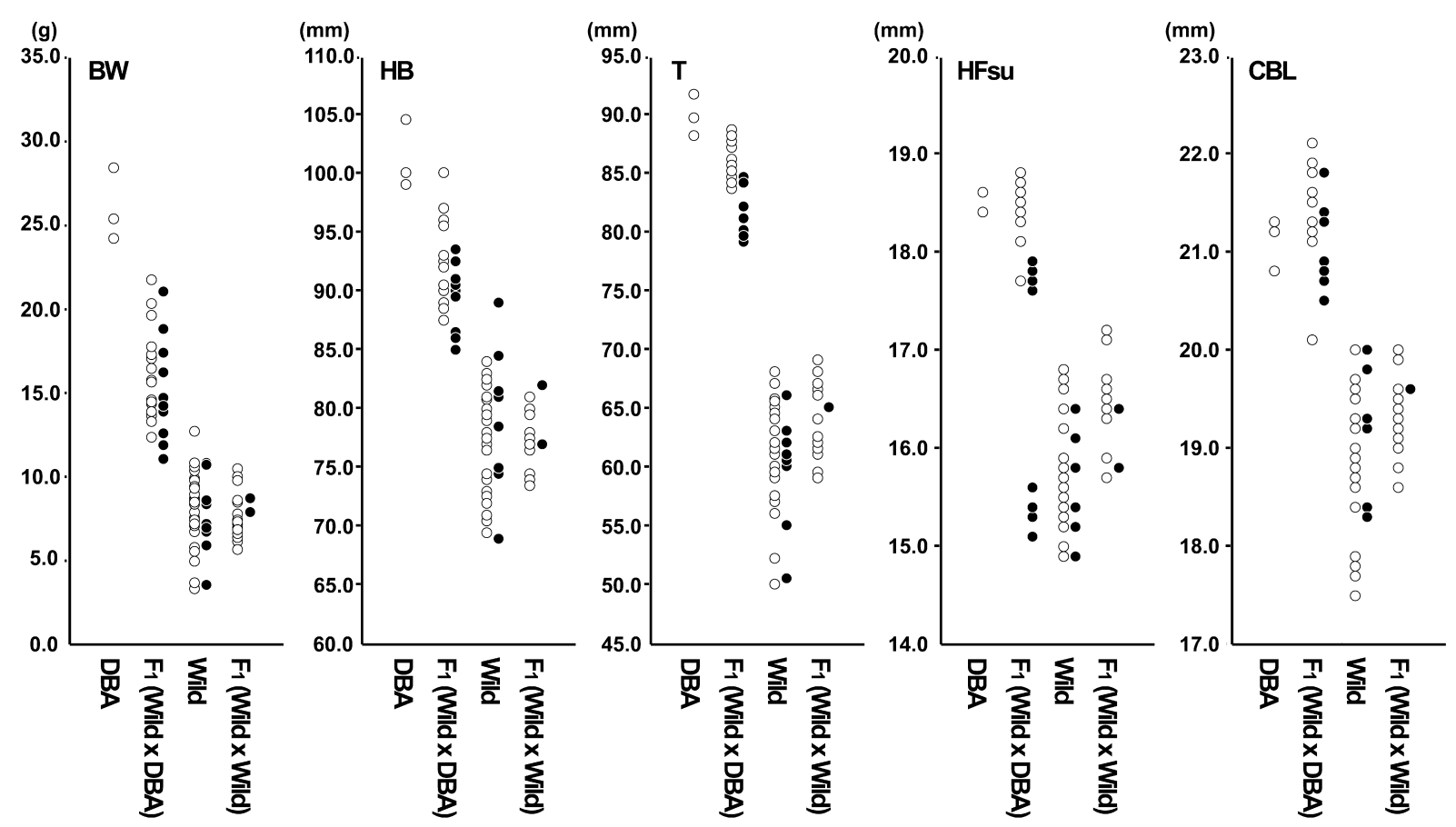

Fig. 4. Comparisons of external morphological measurements among mice examined in this study: DBA/2 (DBA), $F_{1}$ between a wild-caught mouse and DBA/2 (Wild $\times$ DBA), a wild-caught mouse (Wild), and $\mathrm{F}_{1}$ between wild-caught mice (Wild $\times$ Wild). See text for abbreviations of measurements. White and black circles indicate the WL and the IB-BK type individuals, respectively.

(Ooyo-Seibutsu Inc.), Scott J. Bultman (Oak Ridge National Laboratory), Michael W. Nachman (Univ. of Arizona), and Kazuyuki Mekada (RIKEN) for their comments and information. We wish to express our gratitude to Akira Nishizuka, Keiki Matsuda, and Mai Udagawa for their kind help in capturing mice. This study was partially supported by a Grant 2009 for Joint Research of the Life Science Research Center, College of Bioresource Sciences, Nihon University.

\section{References}

1. Bennett, D.C. and Lamoreux, M.L. 2003. The color loci of mice - a genetic century. Pigment Cell Res. 16: 333-344. [Medline]

2. Chen, Y., Dual, D.M., and Barsh, G.S. 1996. Opposite orientations of an inverted duplication and allelic variation at the mouse agouti locus. Genetics 144: 265-277. [Medline]

3. Corbet, G.B. and Hill, J.E. 1992. Genus Mus. pp. 326-331. In: The Mammals of the Indomalayan Region: A Systematic Review, Oxford University Press, New York.

4. Festing, M.F.W. 1994. Inbred strains of mice. Updated 3rd. Aug. 1994. Mouse Genome 92: 373-495.

5. Green, M.C. 1981. Genetic Variants and Strains of the Laboratory Mouse, Gustav Fischer Verlag, Stuttgart.
6. Hamajima, F. 1964. The life history of the Japanese mouse, Mus molossinus Temminck and Schlegel (XI): measurements of external characters, skull and reproductive organs in adult mouse. Sci. Bull. Fac. Agr. Kyushu Univ. 21: 73-83 (in Japanese).

7. Hamajima, F. 1969. Mammals of Japan. 8. Rodentia. Mus. Mamm. Sci. 18: 11-23 (in Japanese).

8. Hoekstra, H.E. 2006. Genetics, development and evolution of adaptive pigmentation in vertebrates. Heredity (Edinb) 97: 222-234. [Medline]

9. Hoekstra, H.E., Hirschmann, R.J., Bundey, R.A., Instel, P.A., and Crossland, J.P. 2006. A single amino acid mutation contributes to adaptive beach mouse color pattern. Science 313: 101-104. [Medline] [CrossRef]

10. Iwasa, M.A. 2009. Mus musculus. p. 179. In: The Wild Mammals of Japan (Ohdachi, S.D., Ishobashi, Y., Iwasa, M.A., and Saitoh, T. eds.), Shoukadoh, Kyoto.

11. Kuroda, N. 1940. A Monograph of the Japanese Mammals, Sanseido, Tokyo (in Japanese).

12. Marshal, J.T. and Sage, R.D. 1981. Taxonomy of the house mouse. Sym. Zool. Soc. Lond. 47: 15-25.

13. Moriwaki, K. 1988. Genetic differentiation of subspecies of Mus musculus. Mamm. Sci. 28: 91-103 (in Japanese).

14. Nachman, M.W., Hoekstra, H.E., and D'Agostino, S.L. 2003. The genetic basis of adaptive melanism in pocket mice. Proc. Natl. Acad. Sci. U.S.A. 100: 5268-5273. [Medline] [CrossRef]

15. Nishimura, M., Kondo, K., Nakamura, H., and Watanabe, T. 
1973. Strains originated from the wild Japanese mouse (Mus musculus molossinus). Jikken Dobutsu 22: 187-193. [Medline]

16. Nomaguchi, T.A. and Sakurai, Y. 1993. Inbreeding Process and establishment of new inbred lines derived from the Japanese house mouse, Mus musculus molossinus. Jikken Dobutsu 42: 175-179 (in Japanese). [Medline]

17. Nunome, M., Suzuki, H., and Moriwaki, K. 2009. Mosaic genome structure of multiple subspecies in the Japanese wild mouse Mus musculus molossinus. pp. 180-181. In: The Wild Mammals of Japan (Ohdachi, S.D., Ishobashi, Y., Iwasa,
M.A., and Saitoh, T. eds.), Shoukadoh, Kyoto.

18. Searle, A.G. 1968. Comparative Genetics of Coat Colour in Mammals, Logos Press, London.

19. Tokuda, M. 1941. A revised monograph of the Japanese and Manchou-Korean Muridae. Transact. Biogeogr. Soc. Jpn. 4: $1-156$.

20. Wada, A., Okumoto, M., and Tsudzuki, M. 1999. Tawny: a novel light coat color mutation found in a wild population of Mus musculus molossinus, a new allele at the Melanocortin 1 Receptor (Mc1r) locus. Exp. Anim. 48: 73-78. [Medline] [CrossRef] 